\title{
Screening for Drought Tolerance in Tepary and Common Bean Based on Osmotic Potential Assays
}

\author{
Jose Cruz Jimenez-Galindo, ${ }^{1,}$, , Lorena Alvarez-Iglesias ${ }^{1}$, Pedro Revilla-Temino ${ }^{1}$, \\ Rodolfo Jacinto-Soto ${ }^{3}$, Luis Enrique Garcia-Dominguez ${ }^{4}$, Maria de La Fuente-Martinez ${ }^{1}$, \\ Rosa Ana Malvar-Pintos ${ }^{1}$, Bernardo Ordas-Lopez ${ }^{1}$, Albert Jody Vander Wal ${ }^{5}$, \\ Juan Manuel Osorno ${ }^{5}$ \\ ${ }^{1}$ Maize Genetics and Breeding, Spanish National Research Council (CSIC), Pontevedra, Spain \\ ${ }^{2}$ Bean Genetics and Breeding, National Institute of Forestry, Agriculture and Livestock Research (INIFAP), Cuauhtemoc, Mexico \\ ${ }^{3}$ Department of Plant Sciences, Autonomous University of Chapingo, Bermejillo, Mexico \\ ${ }^{4}$ Department of Plant Sciences, Autonomous University of Chihuahua, Chihuahua, Mexico \\ ${ }^{5}$ Department of Plant Sciences, North Dakota State University, Fargo, US
}

\section{Email address:}

jimenez.cruz@inifap.gob.mx (J. C. Jiménez-Galindo), cruz2477@yahoo.com.mx(J. C. Jiménez-Galindo)

${ }^{*}$ Corresponding author

\section{To cite this article:}

José Cruz Jiménez-Galindo, Lorena Álvarez-Iglesias, Pedro Revilla, Rodolfo Jacinto-Soto, Luis Enrique García-Domínguez, María de La Fuente, Rosa Ana Malvar, Bernardo Ordás, Albert Jody Vander Wal, Juan Manuel Osorno. Screening for Drought Tolerance in Tepary and Common Bean Based on Osmotic Potential Assays. Plant. Vol. 6, No. 2, 2018, pp. 24-32. doi: 10.11648/j.plant.20180602.11

Received: June 14, 2018; Accepted: July 11, 2018; Published: August 6, 2018

\begin{abstract}
Common bean (Phaseolus vulgaris L.) is the most important food legume grown worldwide. In Mexico, it is a strategic crop, occupying the second place in terms of cultivated area. Drought is the main problem for common bean production in Mexico. Some tepary (Phaseolus acutifolius A. Gray) and common bean genotypes can be a source for drought tolerance to improve commercial cultivars. The main objectives of this study were the evaluation of germination and seedling growth components in response to drought stress and the identification of sources of drought tolerance in both tepary and common bean. The experiment was conducted using various osmotic pressures (OP) induced by polyethylene glycol (PEG6000) $(0,-0.15,-0.30$ and $-0.49 \mathrm{MPa})$ simulating an increase of drought stress in seven common bean and three tepary bean genotypes. The most drought-tolerant genotypes were two tepary beans: Tepary cafe which had a reduced root length of $21.4 \%$ and Tepary negro that decrease root length in a $29.7 \%$ compared to control at high osmotic pressure. Besides, two common beans: Rosa Bufa and Santa Fe (which decreased root length at high osmotic pressure in $46.0 \%$ and $34.2 \%$, respectively) could be used as sources of favorable alleles to improve bean tolerance to drought. There are different strategies to tolerate drought, such as developing a long root, root fresh weight, and root dry weight.
\end{abstract}

Keywords: Tepary Bean, Common Bean, Drought Tolerance, Polyethylene Glycol, Osmotic Pressure

\section{Introduction}

Most of the arable soil of the world is classified as semiarid land and lack of moisture is the principal limiting factor for increasing the world agricultural production [1]. Drought is the main problem to common bean production in Mexico [2]; [3]. Drought can be most simply defined as a period of below normal precipitation that limits plant productivity in a natural or agricultural system [4]. It has been estimated that in Latin America, water stress reduces bean seed yield between $60 \%$ [5] and 73\% [6]. In field trials in the United States, [5] found seed yield losses ranging from $24 \%$ in tolerant beans to $90 \%$ in susceptible beans. [3] found yield reductions from $9.5 \%$ in tolerant beans to $88 \%$ in susceptible beans in Mexico.

Common bean is the most important food legume grown worldwide [7]. It is cultivated in all five continents and, in spite of not being considered one of the four priority crops 
worldwide, it is one of the staples of the people in some regions of Africa, Latin America, and the Caribbean [8]. In Mexico, it is a strategic crop, occupying the second place in terms of cultivated area, with an average of 1,773,996 ha in 2014 , with $1,273,957$ MT produced, with a value of $\$ 528,333$ USD [39]. In 2014, at least $63 \%$ of total bean production in Mexico is located in the states of Zacatecas with 596,944 ha, Durango with 268,485 ha, San Luis Potosi with 127,381 ha, and Chihuahua with 125,315 ha [39].

Drought stress can reduce biomass, number of seeds and pods, days to maturity, harvest index, seed yield, and seed weight in bean [7]. The stress component that defines drought is a decrease in the availability of soil water, which consequently reduces water potential $\psi_{\mathrm{w}}$ [9].

Tepary bean is a crop adapted to hot arid climates and is grown in a small area in the US Southwest and parts of Mexico during summer when temperatures are high and drought occurs [10]. As a member of the tertiary gene pool of common bean, tepary bean is a potential donor of drought tolerance to common bean through interespecific hybridization, although the cross is difficult and requires embryo rescue [11].

[12] found that stomata of tepary bean close completely at -8 and -10 bars of osmotic pressure, delaying dehydration of leaf tissue in tepary bean compared to common bean which do not close their stomata until water potentials between -13 and -18 bars. In addition, tepary bean had a deeply penetrating root system, which also contributes to its drought tolerance[12]). Tepary bean postpones dehydration and suggest that sensitive stomata and a deeply penetrating root system are characteristics which, if incorporated into cultivated beans, might increase their drought tolerance or resistance [12]; [13]; [14]; [15].

The genetic resources of common bean and tepary bean available in Mexico are abundant but so far underused, mainly because of lack of phenotypic/genotypic characterization [16]. Tepary bean is a crop adapted to hot arid climates and is grown in the Southwest of United States and North of Mexico during summer when temperatures and drought are too high for common bean [10]. Likewise, bean genotypes domesticated in the semi-arid regions over millennia, mainly those belonging to race Durango from the Mexican highlands, would be expected to possess higher levels of drought tolerance [17]. Few studies have recently reported new tepary genotypes originating from the deserts and highlands of northern Mexico [18]. In this region, bean genotypes have been exposed to abiotic and biotic factors for thousands of years and therefore, some have developed resistance or tolerance to biotic and abiotic stresses. Previous evaluations of drought tolerance in beans have been carried out under field conditions, which are variable and unstable; such evaluations can be complemented with evaluations under controlled conditions in order to provide reliable data under precise drought pressures. Simulated drought stress with polyethylene glycol (PEG) has proven to be a reliable approach for screening drought tolerance in germplasm collections of maize (Zea mays L.) where water stress was induced by PEG and Quantitative Trait Loci (QTL) were identified for seedling traits at the first leaf stage; their collocation was compared with published yield-related traits found in drought-stress experiments [19]. PEG was also used with barley (Hordeum vulgare L.) where drought stress was imposed by placing the plants in PEG solution at $-0.7 \mathrm{MPa}$, moderate drought for $8 \mathrm{~h}$ at $28^{\circ} \mathrm{C}$ and $40 \%$ relative humidity [20]; water stress in maize, barley, and rice (Oryza sativa L.) was generated by additions of PEG 6000 to the root medium, and found that despite numerous inter-species similarities, biophysical changes associated with stress-induced leaf growth inhibition in maize and barley, differed from those in rice [21]. Evaluation of drought tolerance at early stages of development has been successfully used for screening collections of genotypes of maize [22]; [23]. Therefore, the main objective of this work is to assess drought tolerance in a collection of tepary and common bean in order to identify potential sources of drought tolerance at early stages of development for improving common bean. These genotypes have been chosen to be the base breeding material available for tolerance to drought and for other 13 traits for bean improvement for northern Mexico. These 10 genotypes are currently being used in breeding programs.

\section{Materials and Methods}

Seven $P$. vulgaris and three $P$. acutifolius genotypes with diverse genetic backgrounds were used (Table 1). Four of these genotypes were selected based on their stable and consistent tolerance to drought in field trials: Rosa Bufa and Tepary cafe [3]; Pinto Saltillo [18, 24] and Stampede [25]. The other six genotypes have outstanding agronomic performance and/or quality: Santa Fe [26], Lariat [25], Tepary amarillo, Tepary negro, Dorado [27], and PS-AZH15. PS-AZH-15 is a breeding line generated at INIFAP Cuauhtémoc Chihuahua from a cross between P. Saltillo and Azufrado Higuera, and it has been not released yet. This genotype is very interesting because: 1$)$ it has larger seed size than P. Saltillo (46.3 g vs 30 g per 100 seeds [28], 2) seed type belongs to Nueva Granada race, 3) it shows shorter cooking time (40 minutes vs 56 min for P. Saltillo and 158 min for Pinto Centauro for $100 \%$ of cooked [28], this trait is very important due to that for cooking $1 \mathrm{~kg}$ of beans takes upwards of $7 \mathrm{~kg}$ of firewood, and gathering enough wood for a household takes about 11 hours per week [29], and 4) PSAZH-15 has the same color than P. Saltillo.

This study was conducted in a Lab where seeds were incubated in the dark at $27^{\circ} \mathrm{C}$ and $70 \% \mathrm{RH}$ in a growth chamber, and it was carried out as a complete randomized design (CRD) in a factorial arrangement. Factorial combinations of 10 genotypes and 4 osmotic pressure levels were evaluated with three replications. The experimental plot was one petri dish with 10 or 5 seeds. 10 seeds of each genotype were used per repetition, according to seed availability. Osmotic pressure levels of $0,-0.15,-0.30$ and $0.49 \mathrm{MPa}$ were created using PEG6000 based on the equation supplied by [30]. Seed germination test was done in $13 \mathrm{~cm}$ 
Petri dishes with a layer of filter paper and $10 \mathrm{ml}$ of a dilution containing $0,100,150$, and $200 \mathrm{~g}$ of PEG6000 for reaching an osmotic pressure of $0,-0.15,-0.30$ and -0.49 , respectively. Seeds were considered germinated when the radicle was approximately $2 \mathrm{~mm}$ long or more. After seven days, seedlings root and shoot lengths were measured in centimeters and the same day were weighted the fresh root and shoot in a precision balance in grams. Root and shoot tissue was placed in a stove at $45^{\circ} \mathrm{C}$ for seven days and then dry weights (root and shoot) in $\mathrm{g}$ were recorded. All data were expressed as percent reduction respect to their own control in water with zero of OP.

An ANOVA was made using the GLM (General Linear Model) procedure (PROC GLM) of SAS [40]. The sources of variation were genotype, stress level, and genotype $\times$ stress level interaction. Genotypes, osmotic pressure and genotype $\times$ osmotic pressure interaction were considered fixed effects. Besides, an individual ANOVA by stress level was also carried out. We used the Fisher's protected LSD (Least Significant Difference) at $p<0.05$ for mean comparisons. Principal Component Analyses was conducted with all traits using SAS software [40]. Previously, all data were standardized with mean $=0$ and standard deviation $=1$. The first component was used for ordering genotypes because explained most of the variability across the Osmotic Pressure levels $(\mathrm{OP} 1=55.5 \%, \mathrm{OP} 2=67.5 \%$, and $\mathrm{OP} 3=72.5 \%$ of the variability explained) and It was considered as a drought tolerance index.

Table 1. Seed origin, races, species, drought response, growth habit and seed size of three tepary bean and seven common bean cultivars evaluated for drought tolerance.

\begin{tabular}{|c|c|c|c|c|c|c|}
\hline Genotype & Origin & Race & Species & $\begin{array}{l}\text { Drought Response in } \\
\text { the field }\end{array}$ & Characteristics & $\begin{array}{l}\text { Growth } \\
\text { habit }^{\mathrm{c}}\end{array}$ \\
\hline Rosa Bufa & INIFAP $^{\mathrm{a}}$ & Durango & P. vulgaris & Tolerant & High yield, short cycle (60-80 days) & II \\
\hline T. cafe & INIFAP & Cultivated tepary & P. acutifolius & Tolerant $^{\mathrm{e}}[42]$ & High yield, grain size stability, resistance to Fusarium & III \\
\hline P. Saltillo & INIFAP & Durango & P. vulgaris & Moderately tolerant & $\begin{array}{l}\text { High yield, multiple disease resistant, midseason }(90- \\
120 \text { days), slow darkening, grain size stability }\end{array}$ & III \\
\hline Stampede & $\mathrm{NDSU}^{\mathrm{b}}$ & Durango & P. vulgaris & Tolerant & Upright plant architecture, high yield, resistant to BCMV & II \\
\hline Santa Fe & $M_{S U}{ }^{d}$ & Durango & P. vulgaris & Unknown & Upright plant architecture, multiple disease resistant, & II \\
\hline T. amarillo & INIFAP & Cultivated tepary & P. acutifolius & Unknown & Resistance to $A$. obtectus ${ }^{\mathrm{f}}$ & III \\
\hline T. negro & INIFAP & Cultivated tepary & P. acutifolius & Unknown & Resistance to $A$. obtectus ${ }^{\mathrm{f}}$ & III \\
\hline Dorado & INIFAP & Durango & P. vulgaris & Unknown & High yield, slow darkening, good seed quality & III \\
\hline PS-AZH-15 & INIFAP & N. Granada & P. vulgaris & Unknown & $\begin{array}{l}\text { Reduced cooking time, slow darkening, high grain } \\
\text { quality (see origin) }\end{array}$ & II \\
\hline
\end{tabular}

${ }^{a}$ INIFAP (Campo Experimental Sierra de Chihuahua, Cd. Cuauhtémoc, Chihuahua, México). 'DSU (North Dakota State University, Fargo, North Dakota). ${ }^{\mathrm{c}}$ Growth habit: Type I-determinate bush; Type II-upright short vine, narrow plant profile, three to four branches; Type III-indeterminate, prostrate vine; Type IV-indeterminate with strong climbing tendencies requiring trellis systems for optimal production [41]. ${ }^{\mathrm{d}}$ MSU (Michigan State University). ${ }^{\mathrm{e}}[42] .{ }^{\mathrm{f}}[31]$.

\section{Results}

Genotypes and osmotic pressure showed significant differences for all traits in the combined analysis. We found significant genotype $\times$ osmotic potential interaction for germination, root fresh weight, and root dry weight, but the unique cross interaction was for germination. There was not cross interaction between genotypes and levels of osmotic potential, except for germination. So, tolerant genotypes at low level of osmotic pressure are the same tolerant genotypes at high levels of stress (Table 2).

Table 2. Mean squares of the combined analysis of variance of 10 bean genotypes evaluated with three PEG levels in a growth chamber.

\begin{tabular}{|c|c|c|c|c|c|c|c|c|}
\hline & DF & Germination & Root length & Shoot length & Root fresh weight & Root dry weight & Shoot fresh weight & Shoot dry weight \\
\hline Genotype & 9 & $1214.5 * * *$ & $1621.7 * * *$ & $701.6 * * *$ & $3800.9 * * *$ & $29726.8 * * *$ & $587.2 * * *$ & $2219.4 * * *$ \\
\hline PEG & 2 & $827.7 * * *$ & $7963.3^{* * *}$ & $20933.1 * * *$ & $24313.1 * * *$ & $54074.6 * * *$ & $16655.9 * * *$ & $30773.7 * * *$ \\
\hline Genotype*PEG & 18 & $230.53 * * *$ & $315.05 \mathrm{NS}$ & $273.9 \mathrm{NS}$ & $384.7 *$ & $1838.2 *$ & $63.4 \mathrm{NS}$ & 194.7 NS \\
\hline Error & 18 & 94.3 & 201.1 & 178.7 & 212.9 & 965.1 & 69.09 & 163.1 \\
\hline
\end{tabular}

*Significant at the 0.05 probability level. **Significant at the 0.01 probability level. ***Significant at the 0.001 probability level. NS, not significant.

Individual analysis by osmotic pressure showed significant differences among genotypes for all traits, except for germination, and root length at -0.15 , and shoot length at $0.30 \mathrm{MPa}$ of OP (Table 3). All genotypes have an adequate germination at $-0.49 \mathrm{MPa}$, except PS-AZH-15, and P. Saltillo. Germination decreased when osmotic pressure increased for susceptible genotypes although in some genotypes there are not significant differences. PS-AZH-15 germination decreased at $-0.49 \mathrm{MPa} \quad 64.7 \% \quad(P<.0001)$ compared to control, germination of T. amarillo decreased $21.4 \%(P=0.3689)$, and for P. Saltillo germination decreased $20 \%(P=0.0138)$. Germination was not significantly reduced respect to the control for tolerant genotypes: in $\mathrm{T}$. cafe decreased $3.5 \%(P=0.6646)$, in T. negro $6.7 \%(P=0.4009)$, in Santa $\mathrm{Fe} 0.0 \%(P=1.0)$, in Lariat $6.7 \%(P=0.4009)$, in $\mathrm{R}$. Bufa increased $7.1(P=0.6524)$, in Stampede decreased $0.0 \%$ $(P=1.0)$, and in Dorado increased $3.83 \%(P=0.3324)$ at -0.49 $\mathrm{MPa}$ (Figure 1). 
Table 3. Mean squares of the analysis of variance of 10 bean genotypes evaluated with PEG6000 in a growth chamber in Pontevedra, Spain. LSD $=0.05$. by PEG levels.

\begin{tabular}{|c|c|c|c|c|c|c|c|c|c|}
\hline $\begin{array}{l}\text { PEG } \\
\text { level }\end{array}$ & $\begin{array}{l}\text { Source of } \\
\text { variation }\end{array}$ & DF & Germination & $\begin{array}{l}\text { Root } \\
\text { length }\end{array}$ & $\begin{array}{l}\text { Shoot } \\
\text { length }\end{array}$ & $\begin{array}{l}\text { Root fresh } \\
\text { weight }\end{array}$ & $\begin{array}{l}\text { Root dry } \\
\text { weight }\end{array}$ & $\begin{array}{l}\text { Shoot fresh } \\
\text { weight }\end{array}$ & $\begin{array}{l}\text { Shoot dry } \\
\text { weight }\end{array}$ \\
\hline \multicolumn{10}{|c|}{ PEG -0.15 } \\
\hline & Genotype & 9 & $146.3 \mathrm{NS}$ & $351.3 \mathrm{NS}$ & $982.6^{* *}$ & $2263.3 * *$ & $14240.9 * * *$ & $411.6^{*}$ & $1280.3 * *$ \\
\hline & Error & 19 & 111.8 & 227.02 & 275.4 & 480.6 & 1740.01 & 177.6 & 354.04 \\
\hline \multicolumn{10}{|c|}{ PEG -0.30 } \\
\hline & Genotype & 9 & $247.9 * * *$ & $479.7 * *$ & 174.6NS & $1752.5^{* * *}$ & $13326.8 * * *$ & $219.5 * * *$ & $856.08 * * *$ \\
\hline & Error & 20 & 42.1 & 198.8 & 243.1 & 100.01 & 508.8 & 23.3 & 75.3 \\
\hline \multicolumn{10}{|c|}{ PEG -0.49 } \\
\hline & Genotype & 9 & $1303.6^{* * *}$ & $1417.9 * * *$ & $85.3^{* * *}$ & $549.3 * * *$ & $5779.09 * * *$ & $82.8^{* * *}$ & $478.6^{* * *}$ \\
\hline & Error & 20 & 130.01 & 178.8 & 22.5 & 71.6 & 685.3 & 11.7 & 69.6 \\
\hline
\end{tabular}

*Significant at the 0.05 probability level.

**Significant at the 0.01 probability level.

***Significant at the 0.001 probability level.

NS, not significant.
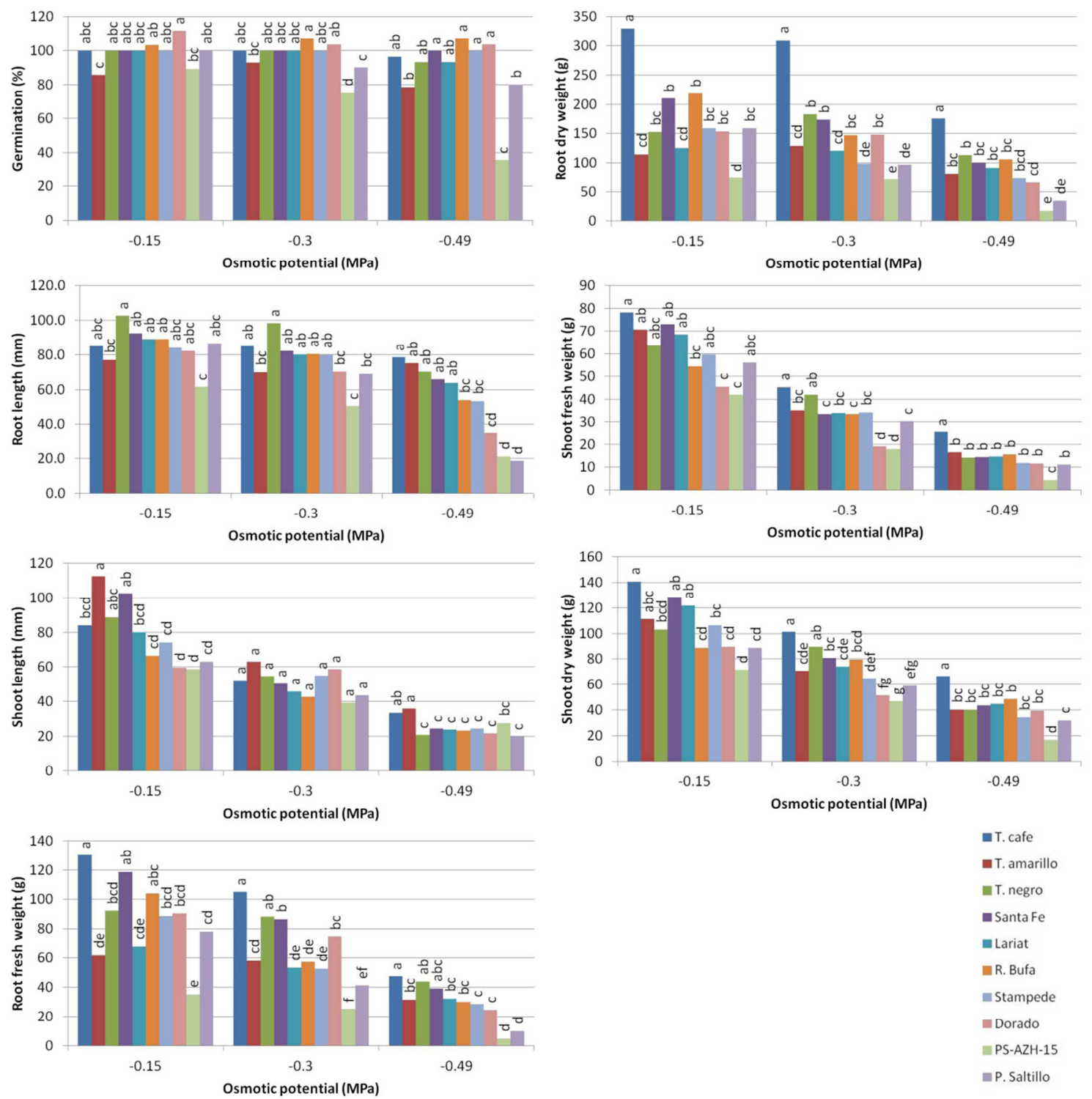

Figure 1. Effects of osmotic potential of ten bean evaluated in vitro under increasing osmotic potential generated by growing concentrations of PEG6000. The control is not shown because is the 100\% for each variety and for each trait. The LSD for the interaction (genotype*PEG) was calculated with the formula $L S D=$ Distribution $T(\alpha-D F) * \sqrt{E} E M S^{*} 2 / n$ repetitions. $E M S$ and $D F$ were taken from the Table 2 per each trait studied, and $\alpha=0.05$. LSD for germination $=16.6$, $L S D$ for root length $=24.3, L S D$ for shoot length $=22.9, L S D$ for root fresh weight $=25.0, L S D$ for root dry weight $=53.2, L S D$ for shoot fresh weight $=14.2$, and $L S D$ for shoot dry weight $=21.9$. 
T. cafe showed the heaviest shoots (fresh and dry) for any osmotic pressure while the lowest shoot weight was showed for PS-AZH-15, and P. Saltillo (Figure 1).

The genotype $\mathrm{T}$. cafe $(P=0.5909)$, maintained root length across increasing osmotic pressure, and was the genotype with the highest root dry weight for all osmotic pressures. Conversely, P. Saltillo and PS-AZH-15 had the lowest values for root length, root fresh weight, and root dry weight (Figure 1).

The results of the multivariate analysis combining all osmotic pressures confirmed the results observed in the univariate analysis (Figure 1 and 3). T. cafe is the most tolerant, followed by T. negro, Santa Fe and R. Bufa. T. cafe has a consistent and stable response as the stress level increases. On the other hand, there is an outstanding positive response of T. negro and R. Bufa when stress level increases. Santa Fe has a good response at low levels of osmotic potential, but a negative response at higher levels.

By osmotic pressure, the first PC1 explains 55.4\% at -0.15 $\mathrm{MPa}, 67.5 \%$ at $-0.30 \mathrm{MPa}$ and $72.5 \%$ at $-0.49 \mathrm{MPa}$. According to the first principal component (it was considered as index of tolerance), the most tolerant genotypes at -0.49 $\mathrm{MPa}$ were T. cafe, T. negro, Santa Fe, and R. Bufa; the first two belonging to $P$. acutifolius and the last two to $P$. vulgaris. Santa $\mathrm{Fe}$ has a good response at $-0.15 \mathrm{MPa}$ and after this decrease. T. negro has a good response until OP reaches -0.49 MPa. PS-AZH-15, and P. Saltillo were the most susceptible genotypes at all levels of osmotic potential (Figure 2).

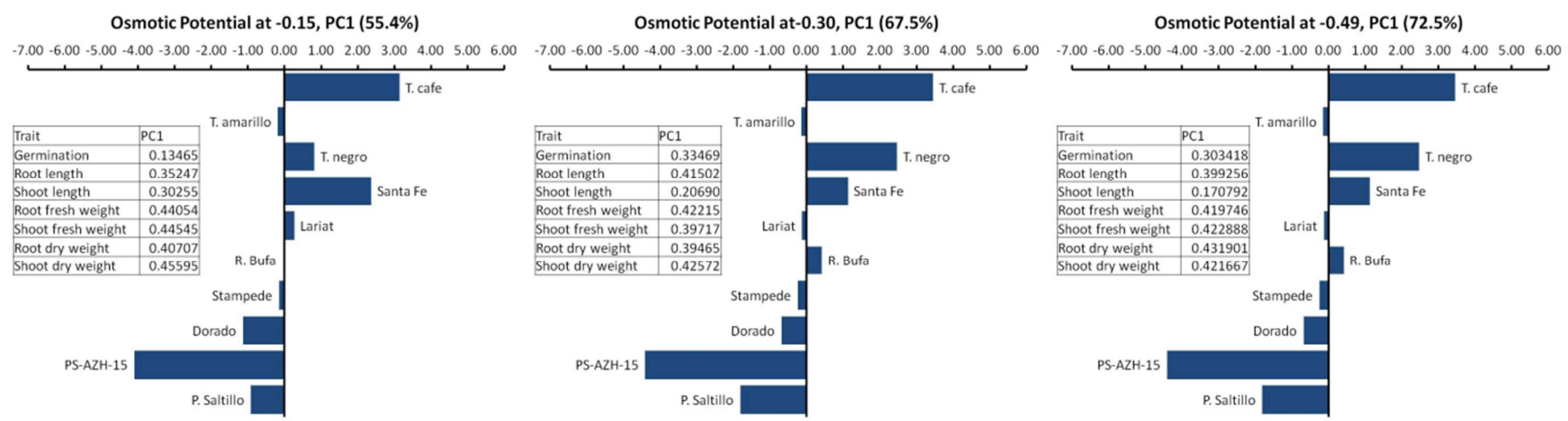

Figure 2. Effects of osmotic potential of ten bean genotypes evaluated in vitro under increasing osmotic potential generated by growing concentrations of $P E G 6000$. We can see if the genotypes respond positively or negatively as the OP level increases.

Principal component analysis shows that T. cafe stands out for its growth and development at three levels of OP (Figure 3). In the A rectangle, it can see $\mathrm{T}$. cafe genotype at the top of the $\mathrm{Y}$ axis and to the right of all genotypes at the $\mathrm{X}$ axis, which means that it is the most resistant genotype at -15 . The same happens in rectangle $\mathrm{C}$ and $\mathrm{D}$ for T. cafe. R. Bufa, Santa Fe and T. negro are also tolerant genotypes.

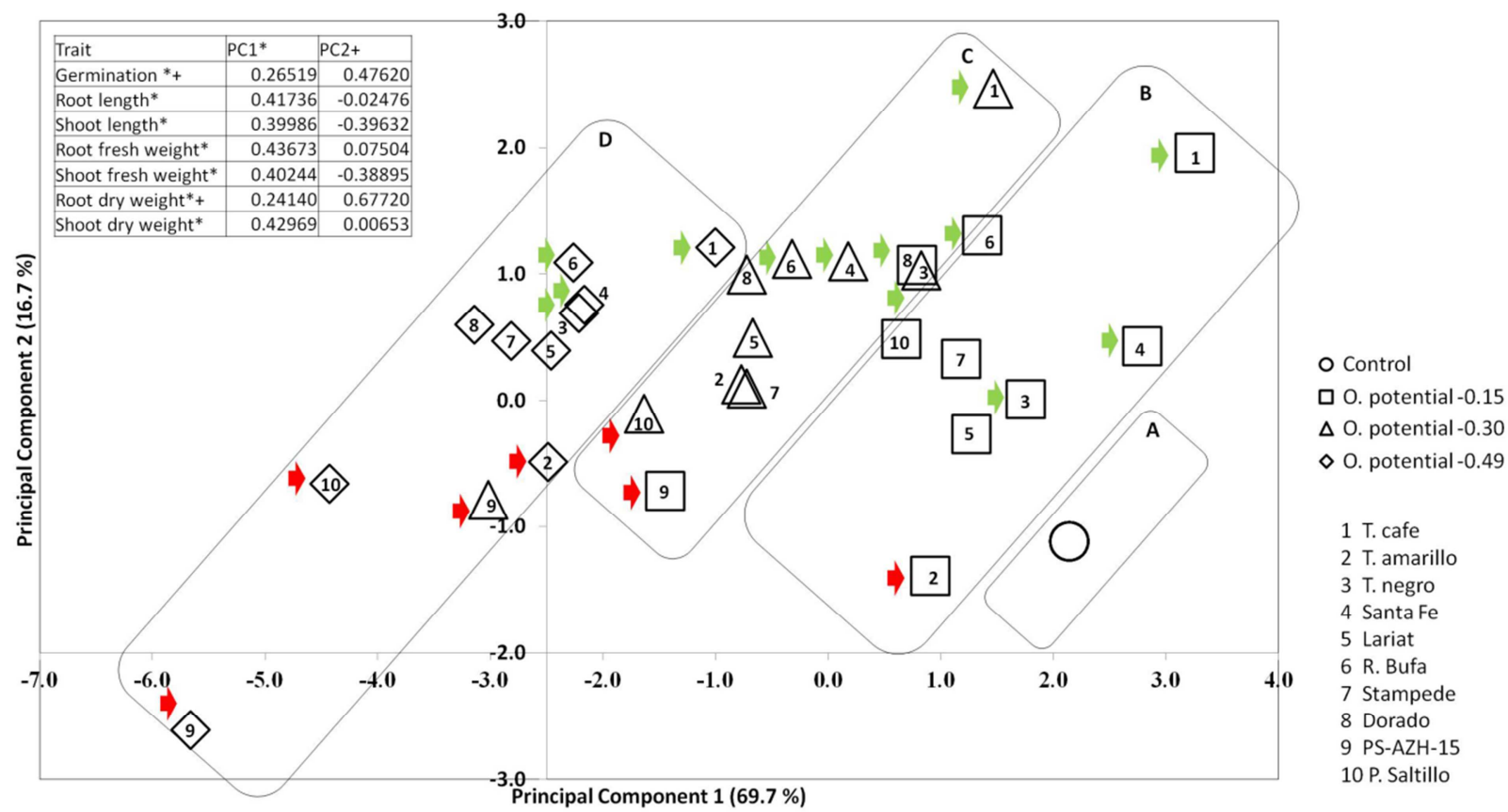

Figure 3. Plot of PC1 vs PC2 for ten bean genotypes and three levels of OP. The green arrows show genotypes with best response to OP, and red arrows show genotypes with worst response. Distribution of genotypes in control in water A, O. potential -0.15 B, O. Potential -0.30 C, and O. potential -0.49 D. We can see the general response to drought. 


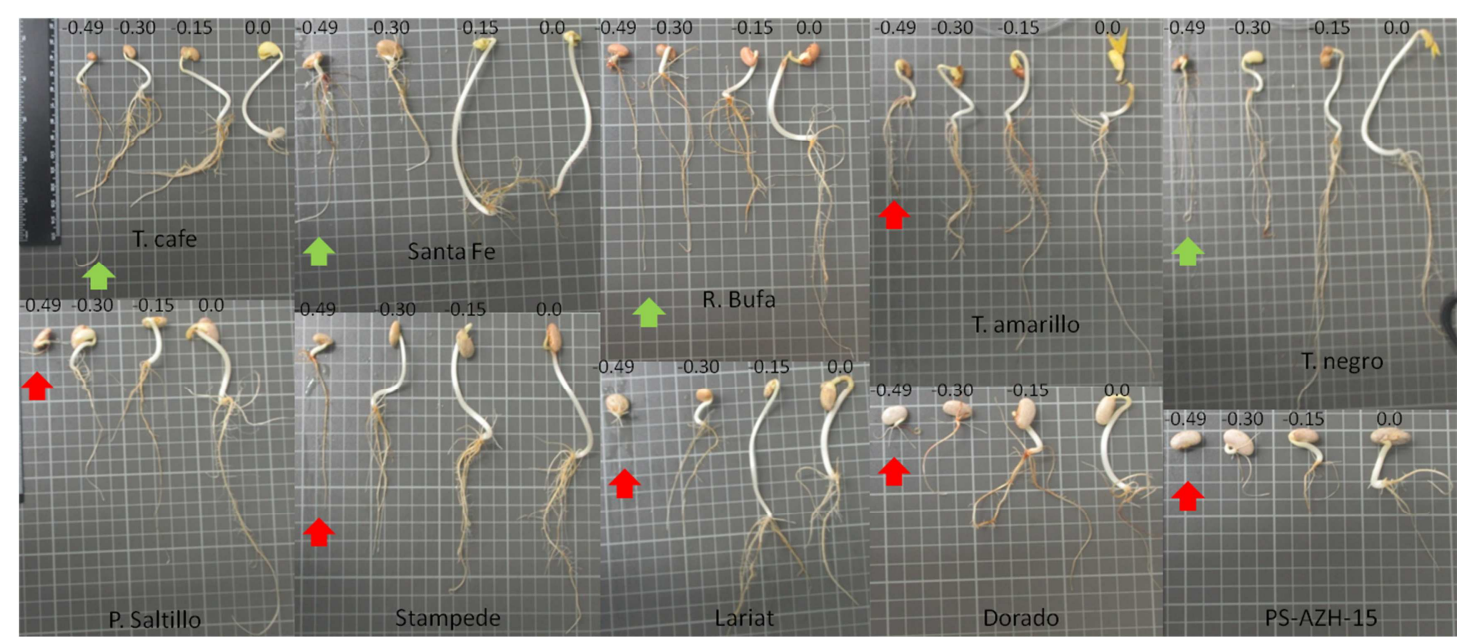

Figure 4. Effects of osmotic potential of ten bean genotypes evaluated in vitro under increasing osmotic potential generated by growing concentrations of $P E G 6000$. Green arrows show the longest roots at $-0.49 \mathrm{MPa}$ of $\mathrm{OP}$, and the red arrows show the shortest roots at $-0.49 \mathrm{MPa}$.

\section{Discussion}

Previous reports of drought tolerance in tepary and common bean are based on adult plant evaluation in field trials, while this study attempts to predict drought tolerance based on simulated osmotic pressure at germination and seedling development. The PEG method has not been widely used in beans to detect tolerant genotypes to drought, but has been used in other crops [19-21]. This method has some advantages because root length or root dry weight cannot be accurately measured in field experiments.

Bean genotypes showed a wide variability for response to osmotic pressure at germination and at early stages of development. Increasing OP decreased root length at -0.49 $\mathrm{MPa}$, respect to the control from $21.4 \%$ in $\mathrm{T}$. cafe to 81.4 in P. Saltillo, shoot length $(64.2 \%$ in T. amarillo to $80.3 \%$ in P. Saltillo), root fresh weight $(52.5 \%$ in T. café to $95.2 \%$ in PSAZH-15), root dry weight (decrease $82.8 \%$ in PS-AZH-15 and increase 75.33 more in T. cafe respect to the control), shoot fresh weight $(74.6 \%$ in $\mathrm{T}$. cafe to $95.6 \%$ in PS-AZH$15)$, and shoot dry weight $(33.6 \%$ in T. cafe to 83.2 in PSAZH-15).

Increasing drought stress progressively decreased germination for susceptible genotypes (PS-AZH-15 and P. Saltillo), as previously reported by [32], and germination was not significantly affected for tolerant genotypes (T. cafe, T. negro, Santa Fe, and R. Bufa). It is very interesting that tolerant genotypes in this study do not decreased the germination level under drought compared to control conditions.

On the other hand, [12] evaluated leaf area expansion, dry weight, and water relations of $P$. vulgaris $L$. and $P$. acutifolius, in the greenhouse. P. acutifolius had a deeply penetrating root system, which also contributes to its drought tolerance. His results indicate that P. acutifolius postpones dehydration and suggest that sensitive stomata and a deeply penetrating root system are characteristics that, if incorporated into cultivated beans, might increase their drought tolerance. Depth of root penetration has been suggested as an important adaptation of Tepary to drought resistance [33]. In this study, Tepary genotypes also showed the longest root at -0.49 but Santa Fe, R. Bufa and Lariat, from $P$. vulgaris, did not differ significant from Tepary genotypes for root length. Therefore, sources of long root under high osmotic potential level can be found within the $P$. vulgaris pool. In addition, T. cafe, T. negro, Santa Fe, and Lariat have great root length development under drought stress and even more at $-0.49 \mathrm{MPa}$, which agrees with previously obtained results by [34] at adult plant level. Root dry weight was higher at all levels of OP for $\mathrm{T}$. cafe, in agreement with the results obtained by [35] for Tepary beans, especially at -0.30 and $-0.49 \mathrm{MPa}$, indicating that $P$. acutifolius was able to produce roots and shoots with higher dry weight than $P$. vulgaris.

Hormesis is a biphasic dose-response of a given chemical compound that is stimulatory at low doses and toxic at high doses [36]. Some genotypes such as T. amarillo and Santa Fe, had good response for shoot length at low levels of OP but poor response as stress increases. It would be interesting to study hormesis in these genotypes in future research.

Our results are in agreement with [3] who found that $T$. cafe was more stable for seed yield under severe drought than R. Bufa, but both were the most tolerant genotypes in the field trials. R. Bufa and T. cafe were more tolerant to drought than P. Saltillo and P. Villa, previously reported as moderately tolerant and tolerant, respectively [37]; The new genotypes found in this study with good response to OP are T. negro and Santa Fe.

In this study, PS-AZH-15 and P. Saltillo were the most susceptible genotypes to OP, which disagree with [18] who found that all 10 genotypes studied were moderately tolerant to drought including P. Saltillo. [18] reported P. Saltillo as tolerant genotype to drought but they used genotypes with limited variability, all were $P$. vulgaris and from the crosses between P. Saltillo and P. Mestizo except Azufrado-2 and the Flor de Mayo. He used a good level of Drought Intensity Index (DII) (53.5-66.0) but reduced variability in the genotypes. In previous studies in field trials, P. Saltillo was 
also considered susceptible because the researchers used wide variability with good level of DII (0.27-0.74) and, therefore, P. Saltillo behaved as a susceptible genotype compared with T. cafe or R. Bufa in field trials [3].

The results obtained for Stampede in this study are in disagreement with the results reported by [38] who found that this genotype was the most top yielding genotype and tolerant to drought from 277 entries in Nebraska (USA), while in our study the results indicated that in this group of genotypes, Stampede behaved as a susceptible genotype. [38] reported Stampede as tolerant genotype in field trials, but those experiments with drought stressed (DS) and non stressed (NS) were irrigated until flowering and irrigation was suspended in (DS) treatment after flowering. Stampede respond to drought after the flowering. With the PEG method we evaluated only at germination and early plant development, and Stampede was identified as a susceptible genotype because we are testing only at seedling stages. In Mexico more than $90 \%$ of bean production is under rainfed conditions and the farmers do not have access to supplemental irrigation.

R. Bufa and Santa Fe could be used for transferring drought tolerance genes to commercial genotypes in short term because these genotypes are $P$. vulgaris. These tolerant donors could be used also for generating mapping populations for genetic studies in crosses with PS-AZH-15 or P. Saltillo. T. cafe and T. negro ( $P$. acutifolius genotypes) could be used to develop mapping population with PS-AZH15 or P. Saltillo ( $P$. vulgaris genotypes) because they were the most contrasting genotypes for drought tolerance traits of $P$. vulgaris in this study. T. cafe and R. Bufa were previously described as having a good response to drought in the field, something which was validated with our experiment [3].

Therefore, tepary bean genotypes, but especially T. cafe and $\mathrm{T}$. negro are a very interesting source of resistance to drought that should be introduced in common bean via interspecific crosses. Simulating drought conditions with polyethylene glycol could be a reliable method for the detection of drought tolerant genotypes of beans and could be used for phenotyping RIL populations or other mapping populations because is in agreement with field trials as our results distinguish the most tolerant genotypes to drought $(\mathrm{T}$. cafe and R. Bufa) from the more susceptible one (P. Saltillo) [3]. The results of this study with PEG method might explain why T. cafe y R. Bufa have good seed yield in field trials. The good response of T. cafe y R. Bufa is probably due to its root length, and according with [12] who evaluated leaf area expansion, and dry weight of Phaseolus vulgaris L. and P. acutifolius, in the greenhouse. P. acutifolius had a deeply penetrating root system, which may also contribute to its drought tolerance.

\section{Conclusion}

The most tolerant genotypes to OP were $\mathrm{T}$. cafe and $\mathrm{T}$. negro, followed by R. Bufa, and Santa Fe. They are a potential source of favorable alleles for drought tolerance and they should be useful for bean improvement. In this study, PS-AZH-15, and P. Saltillo were the most susceptible genotypes to OP. There are different strategies to tolerate drought, such as developing a long root, root fresh weight, and root dry weight.

In germination, there are interactions between genotypes and OP, but the germination is not significantly affected by the osmotic potential. For the other six traits mentioned there is little or no interaction between genotypes and OP, and therefore we can use these traits, highlighting root length and root dry weight, at any level of OP to indirectly select tolerant genotypes to drought. In addition, root traits are more difficult to evaluate in field trials.

Future research should focus on mapping the regions responsible of drought tolerance using the PEG method and field validation for phenotyping this 10 genotypes, RIL, and MAGIC populations.

\section{Availability}

Small quantities of seed of T. cafe, T. amarillo, T. negro, R. Bufa, PS-AZH-15, P. Saltillo and Dorado for research purposes are available from the corresponding author. Stampede, Lariat and Santa Fe should be requested to Dr. J. M. Osorno from North Dakota State University.

\section{Consent for Publication}

All authors have read and approved the final version of the manuscript.

\section{Competing Interests}

The authors declare that they have no competing interests.

\section{Acknowledgements}

José Cruz Jiménez G. is grateful to the National Institute of Forestry, Agriculture and Livestock Research (INIFAP) and the National Council for Science and Technology (CONACYT) in Mexico for the fellowship that supported his $\mathrm{PhD}$ research. This research was supported by the Spanish Plan for Research and Development (project codes AGL2016-77628-R and AGL2015-67313-C2-1-R), Spanish National Research Council (CSIC), and the European Regional Development Fund.

\section{Conflict of Interest}

The authors declare that they have no conflict of interest.

\section{References}

[1] Yang, G.-y., et al., The Response of Winter Wheat Root to the Period and the After-Effect of Soil Water Stress. Agricultural Sciences in China, 2006. 5(4): p. 284-290. 
[2] Acosta-Díaz, E., et al., Adaptation traits in dry bean cultivars grown under drought stress. Agricultura técnica en México, 2009. 35(4): p. 419-428.

[3] Jiménez Galindo, J. C. and J. A. Acosta Gallegos, Rendimiento de frijol común (Phaseolus vulgaris L.) y Tépari (Phaseolus acutifolius A. Gray) bajo el método riego-sequía en Chihuahua. Revista mexicana de ciencias agrícolas, 2013. 4(4): p. 599-610.

[4] Boyer, J. S., PLANT PRODUCTIVITY AND ENVIRONMENT. Science, 1982. 218(4571): p. 443-448.

[5] Brick, M. A., et al., Registration of Drought-Tolerant, RustResistant, High-Yielding Pinto Bean Germplasm Line CO46348. Journal of Plant Registrations, 2008. 2(2): p. 120124.

[6] Van Schoonhoven, A. and O. Voysest, Common beans in Latin America and their constraints. Bean production problems in the tropics, 1989: p. 33-57.

[7] Ramirez-Vallejo, P. and J. D. Kelly, Traits related to drought resistance in common bean. Euphytica, 1998. 99(2): p. 127136.

[8] Lépiz-Ildefonso, R., La contribución de la fitopatología al mejoramiento de los cultivos agrícolas. El Caso Frijol. Revista Mexicana de Fitopatología, 1999. 17(1): p. 54-72.

[9] Kramer, P. J. and J. S. Boyer, Water relations of plants and soils. 1995: Academic press.

[10] Nabhan, G. P. and R. S. Felger, TEPARIES IN SOUTHWESTERN NORTH-AMERICA BIOGEOGRAPHICAL AND ETHNOHISTORICAL STUDY OF PHASEOLUS-ACUTIFOLIUS. Economic Botany, 1978. 32(1): p. 2-19.

[11] Rainey, K. M. and P. D. Griffiths, Evaluation of Phaseolus acutifolius A. Gray plant introductions under high temperatures in a controlled environment. Genetic Resources and Crop Evolution, 2005. 52(2): p. 117-120.

[12] Markhart, A. H., COMPARATIVE WATER RELATIONS OF PHASEOLUS-VULGARIS L AND PHASEOLUSACUTIFOLIUS GRAY. Plant Physiology, 1985. 77(1): p. 113-117.

[13] Rao, I., et al., Can tepary bean be a model for improvement of drought resistance in common bean? African Crop Science Journal, 2013. 21(4)

[14] Blair, M. W., et al., Development of a Mesoamerican intragenepool genetic map for quantitative trait loci detection in a drought tolerant $\times$ susceptible common bean (Phaseolus vulgaris L.) cross. Molecular Breeding, 2012. 29(1): p. 71-88.

[15] Porch, T. G., et al., Use of wild relatives and closely related species to adapt common bean to climate change. Agronomy, 2013. 3(2): p. 433-461.

[16] Jiménez Galindo, J. C. and J. A. Acosta Gallegos, Caracterización de genotipos criollos de frijol Tepari (Phaseolus acutifolius A. Gray) y común (Phaseolus vulgaris L.) bajo temporal. Revista mexicana de ciencias agrícolas, 2012. 3(8): p. 1565-1577.

[17] Singh, S. P., PATTERNS OF VARIATION IN CULTIVATED COMMON BEAN (PHASEOLUS-VULGARIS,

FABACEAE). Economic Botany, 1989. 43(1): p. 39-57.
[18] Osuna-Ceja, E. S., et al., Rendimiento de genotipos de frijol con diferentes métodos de siembra y riego-sequía en Aguascalientes. Revista mexicana de ciencias agrícolas, 2013. 4(8): p. 1209-1221.

[19] Ruta, N., et al., Collocations of QTLs for seedling traits and yield components of tropical maize under water stress conditions. Crop science, 2010. 50(4): p. 1385.

[20] Zhao, F., et al., The difference of physiological and proteomic changes in maize leaves adaptation to drought, heat, and combined both stresses. Frontiers in plant science, 2016. 7.

[21] Lu, Z. and P. M. Neumann, Water-stressed maize, barley and rice seedlings show species diversity in mechanisms of leaf growth inhibition. Journal of Experimental Botany, 1998. 49(329): p. 1945-1952.

[22] Bruce, W. B., G. O. Edmeades, and T. C. Barker, Molecular and physiological approaches to maize improvement for drought tolerance. Journal of experimental botany, 2002. 53(366): p. 13-25.

[23] Khan, N. H., et al., Genetics of drought tolerance at seedling and maturity stages in Zea mays L. Spanish Journal of Agricultural Research, 2016. 14(3): p. 0705.

[24] Sanchez-Valdez, I., et al., Registration of 'Pinto saltillo' common bean. Crop Science, 2004. 44(5): p. 1865-1866.

[25] Osorno, J. M., et al., Registration of 'Lariat' and 'Stampede' Pinto Beans. Journal of Plant Registrations, 2010. 4(1): p. 511.

[26] Kelly, J. D., G. V. Varner, and B. Long, Registration of 'Santa Fe' Pinto Bean. Journal of Plant Registrations, 2010. 4(1): p. 12-16.

[27] Herrera, M. D., J. C. Jiménez-Galindo, and R. Rosales Serna, Dorado, nueva variedad de frijol pinto para el estado de Chihuahua. Revista mexicana de ciencias agrícolas, 2012. 3(7): p. 1459-1466.

[28] Rosales-Serna, R., et al., Rendimiento, preferencia y calidad de enlatado de variedades de frijol pinto producidas en Durango, México. Revista mexicana de ciencias agrícolas, 2014. 5(2): p. 309-315.

[29] Meadows, R., The quest for quick cooking Beans. Crops, Soils, Agronomy News, 2016. 61(5): p. 4-7.

[30] Michel, B. E. and M. R. Kaufmann, OSMOTIC POTENTIAL OF POLYETHYLENE-GLYCOL 6000. Plant Physiology, 1973. 51(5): p. 914-916.

[31] Jiménez, J. C., et al., Resistance categories to Acanthoscelides obtectus (Coleoptera: Bruchidae) in tepary bean (Phaseolus acutifolius), new sources of resistance for dry bean (Phaseolus vulgaris) breeding. Crop Protection, 2017. 98: p. 255-266.

[32] Gholami, A., et al., Germination of different seed size of pinto bean cultivars as affected by salinity and drought stress. Journal of Food Agriculture \& Environment, 2009. 7(2): p. 555-558.

[33] Thomas, C. V. and J. G. Waines, FERTILE BACKCROSS AND ALLOTETRAPLOID PLANTS FROM CROSSES BETWEEN TEPARY BEANS AND COMMON BEANS. Journal of Heredity, 1984. 75(2): p. 93-98.

[34] Mohamed, M. F., et al., Dehydration-avoidance responses of tepary bean lines differing in drought resistance. Journal of Plant Physiology, 2002. 159(1): p. 31-38. 
[35] Turkan, I., et al., Differential responses of lipid peroxidation and antioxidants in the leaves of drought-tolerant P-acutifolius Gray and drought-sensitive P-vulgaris L. subjected to polyethylene glycol mediated water stress. Plant Science, 2005. 168(1): p. 223-231.

[36] Mallqui, K. S. V., et al., Azadirachtin-Induced Hormesis Mediating Shift in Fecundity-Longevity Trade-Off in the Mexican Bean Weevil (Chrysomelidae: Bruchinae). Journal of Economic Entomology, 2014. 107(2): p. 860-866.

[37] Teran, H. and S. P. Singh, Comparison of sources and lines selected for drought resistance in common bean. Crop Science, 2002. 42(1): p. 64-70.

[38] Urrea, C. A. and T. Porch, Phenotypic evaluation of a subset of the Phaseolus vulgaris core collections and the $P$. acutifolius germplasm collection, and advanced common bean lines for drought tolerance in Nebraska. COOPERATIVE, 2009: p. 104.
[39] SAGARPA (Secretaría de Agricultura Ganadería, Desarrollo Rural, Pesca y Alimentación). 2016. Anuarios Estadísticos de la Producción Agrícola. Servicio de Información Agroalimentaria y Pesquera (SIAP). D. F., México. URL: http://www.siap.gob.mx/.

[40] SAS Institute (2016) Version 9.4. SAS Institute, Cary, NC.

[41] NDSU. 2013. Dry ean production guide. Bull. A-1133. NDSU Ext. Serv., Fargo, ND. URL: https://www.ag.ndsu.edu/publications/landingpages/crops/dry-bean-production-guide-a-1133

[42] Jiménez Galindo J. C., Acosta Gallegos J. A. (2013) Rendimiento de frijol común (Phaseolus vulgaris L.) y Tépari (Phaseolus acutifolius A. Gray) bajo el método riego-sequía en Chihuahua. Revista mexicana de ciencias agrícolas 4:599-610. 